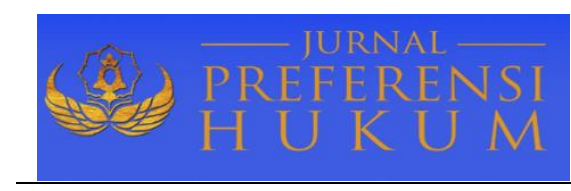

Jurnal Preferensi Hukum | ISSN: 2746-5039

Vol. 2, No. 1 -Februari 2021, Hal. 202-206| Available online at https://www.ejournal.warmadewa.ac.id/index.php/juprehum

DOI: https://doi.org/10.22225/jph.2.1.3068.202-206

\title{
PENERAPAN DIVERSI MELALUI PENDEKATAN KEADILAN RESTORATIF (RESTORATIVE JUSTICE) PADA ANAK PELAKU PENYALAHGUNAAN NARKOTIKA
}

\author{
Putu Ayu Sarina Selsa Oktaviani, A.A. Sagung Laksmi Dewi, I Nyoman Gede Sugiartha \\ Fakultas Hukum Universitas Warmadewa, Denpasar-Bali, Indonesia
}

\begin{abstract}
Abstrak
Diversi merupakan salah satu alternatif yang sesuai dengan konvensi hukum internasional yang merupakan proses penyelesaian perkara anak yang berhadapan dengan hukum dari jalur penal (peradilan) ke jalur non-penal (diluar peradilan). Penelitian ini bertujuan untuk menjelaskan pengaturan diversi terhadap anak berdasarkan UndangUndang tentang Sistem Peradilan Pidana Anak dan menjelaskan penerapan diversi melalui pendekatan keadilan restoratif pada tindak pidana anak pelaku penyalahgunaan narkotika. Metode penelitian yang digunakan ialah penelitian hukum normatif dengan pendekatan perundang-undangan. Sumber bahan hukum yang digunakan adalah sumber bahan hukum primer yaitu peraturan perundang-undangan yang mengatur tentang narkotika serta bahan hukum sekunder yang berupa buku-buku, jurnal ilmiah, laporan ilmiah dan karya ilmiah lainnya yang berhubungan dengan masalah yang sedang diteliti. Data diperoleh dengan cara mencatat, mengutip berdasarkan perundang-undangan yang terkait dengan permasalahan yang diteliti dalam penulisan ini, selanjutnya dianalisis secara deskritif. Hasil penelitian menunjukkan bahwa Pengaturan mengenai diversi diatur dalam undang-undang sistem peradilan pidana anak Pasal 6 sampai dengan Pasal 15, yang pada prinsipnya diversi itu merupakan upaya penyelesaian perkara atau tindak pidana anak melalui upaya penyelesaian di tingkat penyidikan tanpa melalui proses peradilan, selanjutnya Penerapan diversi terhadap penyalahgunaan narkotika bagi anak dilakukan dengan prosedur musyawarah sesuai dengan ketentuan Pasal 8 UU Sistem Peradilan Pidana Anak, dimana pihak pelaku, orang tua, penyidik, hakim anak, lembaga masyarakat professional dan dari lembaga sosial dalam musyawarah atau pelaksanaan diversi tersebut sepakat bahwa proses hukum terhadap pelaku penyalahgunaan narkotika bagi anak tersebut tidak dilanjutkan melalui proses peradilan tetapi dikembalikan pendidikan serta pengawasannya kepada orang tua.
\end{abstract}

Kata kunci: Pidana Anak; Diversi; Narkotika

\begin{abstract}
Diversion is an alternative that is in accordance with international legal conventions, which is the process of solving cases of children in conflict with the law from the penal (judiciary) to the non-penal (outside the court). This study aims to explain the diversion arrangements against children based on the Law on the Criminal Justice System for Children and to explain the application of diversion through a restorative justice approach to the criminal offenses of children who abuse narcotics. The research method used is normative legal research with a statutory approach. The source of legal materials used is the source of primary legal materials, namely the laws and regulations governing narcotics as well as secondary legal materials in the form of books, scientific journals, scientific reports and other scientific works related to the problem being researched. Data obtained by taking notes, quoting based on the laws related to the problems studied in this paper, then analyzed descriptively. The results show that the regulation regarding diversion is regulated in the law on the juvenile criminal justice system Article 6 to Article 15, which in principle, diversion is an attempt to resolve cases or child crimes through resolutions at the level of investigation without going through a judicial process, then The abuse of narcotics for children is carried out by deliberation procedures in accordance with the provisions of Article 8 of the Law on the Criminal Justice System for Children, where the perpetrator, parents, investigators, child judges, professional community institutions and from social institutions in the deliberation or implementation of the diversion agree that the legal process against the perpetrator of narcotics abuse for the child is not continued through the judicial process but his education and supervision are returned to the parents.
\end{abstract}

Keywords: Child Criminal; Diversion; Narcotics

\section{PENDAHULUAN}

Anak merupakan generasi penerus cita-cita dan perjuangan bangsa yang memerlukan pembinaan dan perlindungan khusus untuk menjamin pertumbuhan dan perkembangan anak baik dari fisik, mental maupun sosial anak secara utuh. Ruang lingkup perlindungan anak mencakup perlindungan terhadap kebebasan, hak-hak anak hingga kepentingan dan kesejahteraan anak (Fitriani, 2016). Sesuai amanat 
yang tercemin dalam Undang-undang Dasar Negara Republik Indonesia Tahun 1945 Pasal 28 B ayat (2) yang menyatakan setiap anak berhak atas kelangsungan untuk hidup, tumbuh dan berkembang serta berhak atas perlindungan dari kekerasan dan juga diskriminasi (Sahetapy, 2016); (Sosiawan, 2016).

Indonesia telah mengatur beberapa Undang-undang yang ditunjukkan khusus untuk melindungi hak-hak anak, seperti Undang-Undang tentang Pengadilan anak. Namun jika dibandingkan dengan The Beijing Rules, Undang-Undang Pengadilan Anak memiliki kekurangan yaitu tidak terdapat aturan yang membahas mengenai diversi, sehingga sebagai gantinya dibentuklah Undang-Undang tentang sistem peradila pidana anak, dimana terdapat pengaturan mengenai diversi.

Diversi merupakan salah satu alternatif yang sesuai dengan konvensi hukum internasional yang merupakan proses penyelesaian perkara anak yang berhadapan dengan hukum dari jalur penal (peradilan) ke jalur non-penal (diluar peradilan) (Hambali, 2019). Selain itu dalam diatur juga dalam perma ,Point penting dari PERMA tersebut menyatakan bahwa hakim wajib menyelesaiakn persoalan anak yang berhadapan dengan hukum melalui diversi yang merupakan prosedur hukum yang masih anyar dalam sistem dan pembaharuan hukum pidana di Indonesia.

Seiring perkembangan zaman banyak sekali hal-hal yang dapat mempengaruhi pertumbuhan dan perkembangan anak. Banyak faktor-faktor yang dapat menjerumuskan anak ke dalam hal-hal yang berbau negatif, baik itu faktor dari dalam yang merupakan diri sendiri maupun faktor dari luar yaitu dari lingkungan sekitar seperti kekerasan, seks bebas hingga narkotika (Wiharsa, 2017).

Penyalahgunaan narkotika tidak luput dari gaya pergaulan yang bebas dan juga pengaruh keluarga yang memiliki andil yang besar. Penggunaan narkortika yang mana biasanya sering terjadi dikalangan orang dewasa, justru kini banyak disalahgunakan oleh anak yang masih dibawah umur. Hal ini tentunya dapat memperburuk pertumbuhan dan perkembangan anak. Untuk mencegah dan memberantas penyalahgunaan narkotika yang banyak menimbulkan dampak negatif bagi masyarakat, bangsa dan Negara, maka pada sidang umum MPR Tahun 2002 telah merekomendasikan kepada DPR RI dan Presiden RI untuk melakukan perubahan atas Undang-Undang Narkotika Nomor 35 Tahun 2009.

Terkait penelitian ini, ada beberapa peneliti sebelumnya mengkaji masalah yang relevan dengan penelitian ini, yaitu Nugraha \& Handoyo, (2019) mengungkapkan bahwa perlindungan hukum terhadap anak yang melakukan tindak pidana narkotika diantaranya adalah penghindaran dari penangkapan, penahanan atau penjara; pemberian keadilan di muka pengadilan anak yang obyektif, tidak memihak dan dalam sidang yang tertutup untuk umum; penghindaran dari publikasi atas identitasnya; pemberian pendampingan orang tua/wali dan orang yang dipercayai oleh anak; dan pemberian advokasi sosial, penelitian lain mengkaji tentang penerapan sanksi dalam meminimalisir kejahatan anak ditinjau dari undang undang nomor 11 tahun 2012 tentang sistem peradilan pidana anak (Pancasilawati, 2018). Penelitian lain mengkaji tentang perlindungan hukum terhadap anak korban kekerasan dalam rumah tangga dalam sistem hukum di Indonesia (Kobandaha, 2017). Sampai saat ini diketahui bahwa perlindugan anak terhadap penyalahgunaan narkotika masih belum efektif, oleh sebab itu penelitian ini dilakukan bertujuan untuk untuk menjelaskan pengaturan diversi terhadap anak berdasarkan UndangUndang tentang Sistem Peradilan Pidana Anak dan menjelaskan penerapan diversi melalui pendekatan keadilan restoratif pada tindak pidana anak pelaku penyalahgunaan narkotika

\section{METODE PENELITIAN}

Penelitian ini menggunakan pelenitian hukum normatif yaitu suatu prosedur ilmiah untuk menemukan kebenaran logika keilmuan hukum dari sisi normatifnya. Pendekatan masalah yang digunakan dalam penulisan ini ialah pendekatan perundang-undangan dan pasal-pasal serta doktrin atau pandangan dari para ahli yang berkaitan dengan masalah yang dihadapi terpaut dengan diversi dan narkotika pada anak. Sumber bahan hukum yang digunakan yaitu sumber bahan hukum primer berupa peraturan perundangundangan yang mengatur tentang dan narkotika serta bahan hukum sekunder yang berupa buku-buku, jurnal ilmiah, laporan ilmiah dan karya ilmiah lainnya yang berhubungan dengan masalah yang sedang diteliti. Pengumpulan bahan hukum dengan cara mencatat, mengutip berdasarkan perundang-undangan yang terkait dengan permasalahan yang sedang diteliti. Setelah semuanya data terkumpul selanjutnya dianalisis secara deskritif (Sugiyono, 2013).

\section{HASIL DAN PEMBAHASAN}

1. Pengaturan Diversi terhadap Anak Berdasarkan Undang-undang Nomor 11 Tahun 2012 tentang Sistem Peradilan Pidana Anak 
Kata diversi berasal dari kata bahasa Inggris diversion, menjadi istilah diversi. Penyesuaian akhiransion, -tion menjadi -si. Oleh karena itu, diversion di Indonesia menjadi diversi. secara konseptual, diversi adalah suatu mekanisme yang memungkinkan anak dialihkan dari proses peradilan menuju proses pelayanan sosial.

Pengertian diversi berdasarkan ketentuan Undang-Undang Sistem Peradilan Pidana Anak menjelaskan bahwa diversi merupakan pengalihan perkara anak dari proses peradilan pidana ke proses diluar peradilan pidana. Adapun jenis-jenis diversi secara garis besar terdiri dari 3 (tiga) jenis, yaitu peringatan, diversi informal dan diversi formal. Substansi yang paling mendasar ini ialah pengatura secara tegas mengenai keadilan restoratif dan diversi. Tujuannya disini ialah untuk mencapai perdamaian antara anak dan korban, menyelesaikan perkara anak dari proses peradilan dan menanamkan rasa tanggung jawab terhadap anak. Selain itu aparat penegak hukum juga dalam menjalankan tugas harus mempunyai tujuan yang sama sesuai dengan ketentuan perundang-undangan.

Adapun pelaksanaan diversi dalam perkara anak ini juga memiiki ketentuan sesuai dengan Undang-undang Nomor 11 Tahun 2012 pasal 7, dimana ketentuan diversi disini dimaksudkan dapat dilakukan apabila perbuatan pidana yang dilakukan oleh anak ini ancaman hukumannya dibawah 7 (tujuh) tahun dan bukan pengulangan pidana baik tindak pidana yang sama maupun berbeda, karena mengingat apabila ancaman hukuman pidana diatas 7 (tujuh) tahun merupakan tergolong tindak pidana berat dan melakukan pengungalangan tindak pidana tersebut membuktikan bahwa tujuan dari diversi yang dilakukan itu tidak tercapai.

Pelaksanaan diversi dilakukan melalui musyawarah yang juga dihadiri oleh anak, korban, orangtua, pembimbing kemasyarakatan serta pihak lainnya yang terkait dalam pelaksanaan diversi sesuai dengan ketentuan Undang-Undang Sistem peradilan Pidana yang mana proses diversi dilakukan untuk mebahas mengenai penyelesaian perkara anak agar mencapai kesepakata bersama antara para pihak yang juga dengan memperhatikan kepentingan anak dan korban, yang selanjutnya hasil dari kesepakatan tersebut dapat di laksanakan oleh anak. Adapaun hasil dari kesepakatan diversi tersebut jika dilhat berdasarkan Undang-undang Sistem Peradilan Pidana Pasal 11, dapat berbentuk:

a. Perdamaian yang dengan atau tanpa ganti rugi;

b. Penyerahan kembali terhadap orangtua atau wali;

c. Ikutserta dalam pendidikan dilembaga pendidikan atau LPKS paling lama 3 (tiga) bulan atau;

d. Pelayanan masyarakat.

Pelaksanaan dari hasil kesepakatan diversi tersebut tentunya juga harus diawasi baik itu dari orang tua, masyarakat setempat hingga penjabat yang berwenang seperti kepolisian, kejaksaan hingga ketua pengadilan sesuai dengan dimana proses diversi tersebut dilakukan agar dapat diketahui apakah hasil dari kesepakatan tersebut dilaksanakan atau tidak oleh anak yang berhadapan dengan hukum.

\section{Penerapan Diversi Pada Anak Pelaku Penyalahgunaan Narkotika}

Secara umum, narkotika merupakan sejenis zat baik itu sintesis maupun semi sintesis yang mengakibatkan pengaruh-pengaruh tertentu terhadap tubuh orang yang menggunakannya, seperti hilangnya kesadaran, sebagai perangsang namun bukan merupakan rangsangan sex, dan juga dapat menimbulkan halusinasi (Soedjono.D, 1976).

Narkotika diatur dalam Undang-undang Narkotika Nomor 35 Tahun 2009, dimana dapat digolongkan menjadi 3 golongan, yaitu:

1. Narkotika golongan I, yaitu narotika yang hanya dapat digunakan untuk kepentingan pengembangan ilmu pengetahuan, narkotika golongan I ini dilarang untuk diproduksi atau digunakan hanya terbatas untuk kepentingan tertentu saja karena narkotika golongan I ini memiliki potensi yang sangat tinggi yang mengakibatkan ketergantungan.

2. Narkotika golongan II, yaitu narkotika yang juga berkhasiat untuk pengobatan dan terapi, selain itu juga hanya digunakan untuk kepentingan pengemangan ilmu pengetahuan. Narkotika golongan II ini juga mengakibatkan ketergantungan pada tubuh si pemakai.

3. Narkotika golongan III, kegunaan narkotika golongan III ini hamper sama halnya dengan narkotika golongan II, namun mempunyai potensi yang ringan yang menyebabkan ketergantungan pada si pemakai.

Pada umumnya secara keseluruhan faktor penyebab terjadinya tindak pidana narkotika dapat dibedakan menjadi 2 (dua) kelompok, yaitu:

1. Faktor Internal Pelaku 
Faktor internal pelaku tersebut meliputi berbagai macam penyebab kejiwaan dari diri pelaku yang mendorong seseorang menyalahgunakan narkotika, antara lain:
a. Perasaan egois
b. Kehendak ingin bebas
c. Kegoncangan jiwa
d. Rasa keingin tahuan.

2. Faktor Eksternal Pelaku

Faktor eksternal dari pelau disini biasanya datang dari luar, meliputi:

a. Keadaan ekonomi

b. Pergaulan atau lingkungan

c. Kemudahan

d. Kurangnya pengawasan

e. Ketidaksenangan dengan keadaan sosial

Anak yang terlbat dalam penyalahgunaan narkotika tidak lahir dengan tiba-tiba, tentunya ada pengaruh dari sindikat peredaran narkotika, dimana kejahatan tersebut tentunya juga menjanjikan keuntungan yang cukup menggiurkan. (Ronny \& Nitibaskara, 2001). Dalam Undang-undangNarkotika, tidak mengatur secara khusus tentang ketentuan sanksi pidana pada anak, karena pada umumnya seorang anak yang melakukan suatu tindak pidana akan secara khusus diatur melalui Undang-undang SistemPeradilan Pidana Anak.

Seperti halnya dalam perkara penyalahgunaan narkotika yang dilakukan oleh anak yang terjadi di wilayah Kabupaten Tabanan, dimana anak tersebut ditangkap oleh polisi dengan kedapatan membawa narkotika golongan I yang berjenis tembakau gorilla dengan berat 2,20 (dua koma dua puluh) gram bruto atau 2,0 (dua koma nol) gram netto, yang kemudian dari hasil pemeriksaan oleh polisi yang selanjutnya berkas perkara tersebut kemudian dilimpahkan kepada penuntut umum, dimana dalam perkara ini Jaksa Penuntut Umum melimpahkan dakwaan terhadap perbuatan anak tersebut didakwa dengan ancaman pidana penjara paling lama 4 (empat) tahun dan denda paling banyak Rp. 8.000.000.000,- (Delapan Milyar Rupiah).

Namun karena dalam perkara ini yang melakukan suatu perbuatan pidana ialah seorang anak yang masih dibawah umur maka proses penyelesaian perkara tersbut tidak bisa disamakan dengan proses yang dilakukan terhadap orang dewasa, melainkan melalui diversi sesuai dengan ketentuan UU Sistem Peradilan Pidana Anak. Selain itu terdapat pula hal-hal yang dapat meringankan dan memberatkan yang menjadi pertimbangan dari hakim anak beserta fasilitator diversi dalam mencapai kesepakatan diversi tersebut.

Berdasarkan pertimbangan fasilitator diversi dalam perkara anak di Pengadilan Negeri Tabanan, telah dicapai kesepakatan diversi dengan ketentuan-ketentuan sebagai berikut:

1. Mengembalikan si anak untuk dibina oleh bapak dan ibu kandungnya;

2. Apabila kesepakatan ini tidak dipenuhi dalam jangka waktu 30 (tiga puluh) hari oleh si anak dan pihak-pihak terkait maka proses pemeriksaan perkara dilanjutkan dalam proses persidangan;

3. Anak tersebut berjanji tidak akan mengulangi melakukan tindak pidana lagi;

4. Kesepakatan ini dibuat oleh para pihak tanpa adanya unsur paksaan, kekeliruan dan penipuan dari pihak manapun.

\section{SIMPULAN DAN SARAN}

\section{Simpulan}

Berdasarkan hasil analisis datas, dapat disimpulkan bahwa Hasil penelitian menunjukkan bahwa Pengaturan mengenai diversi diatur dalam undang-undang sistem peradilan pidana anak Pasal 6 sampai dengan Pasal 15, yang pada prinsipnya diversi itu merupakan upaya penyelesaian perkara atau tindak pidana anak melalui upaya penyelesaian di tingkat penyidikan tanpa melalui proses peradilan, selanjutnya Penerapan diversi terhadap penyalahgunaan narkotika bagi anak dilakukan dengan prosedur musyawarah sesuai dengan ketentuan Pasal 8 UU Sistem Peradilan Pidana Anak, dimana pihak pelaku, orang tua, penyidik, hakim anak, lembaga masyarakat professional dan dari lembaga sosial dalam musyawarah atau pelaksanaan diversi tersebut sepakat bahwa proses hukum terhadap pelaku penyalahgunaan narkotika bagi anak tersebut tidak dilanjutkan melalui proses peradilan tetapi dikembalikan pendidikan serta pengawasannya kepada orang tua. 


\section{Saran}

Dari hasil penelitian yang telah dikemukakan, maka adapun yang menjadi saran yaitu Terhadap pengaturan mengenai diversi baik dalam tingkat penyidikan penuntutan maupun pemeriksaan di persidangan harus mengacu pada UU Nomor 11 Tahun 2012 dan Perma Nomor 4 Tahun 2014 sebagai bahan acuan bagi aparat penegak hukum dalam melakukan upaya diversi, selanjutnya penerapan proses diversi terhadap anak yang dimana hasil dari kesepakatan diversi tersebut selain adanya pengawasan dari orangtua, pemerintah setempat dan juga pembimbing kemasyarakatan, harus adanya pelaporan dari pelaksaan hasil kesepakatan itu yang dilaporkan kepada ketua Pengadilan Negeri.

\section{DAFTAR PUSTAKA}

Fitriani, R. (2016). Peranan Penyelenggara Perlindungan Anak Dalam Melindungi Dan Memenuhi Hak-Hak Anak. Jurnal Hukum Samudra Keadilan, 11(2), 250-358.

Hambali, A. R. (2019). Penerapan Diversi terhadap Anak yang Berhadapan dengan Hukum dalam Sistem Peradilan Pidana. Jurnal Penerapan Diversi Terhadap Anak, 13(1), 15-30.

Kobandaha, M. (2017). Dosen Fakultas Hukum Universitas Pembangunan Indonesia Manado dan Pengacara Praktek di Kota Kotamobagu 1 82. Jurnal Hukum Unsrat, 23(8), 82-91.

Nugraha, W., \& Handoyo, S. (2019). Penerapan Restorative Justice dalam Penanganan dan Penyelesaian Tindak Pidana Narkotika yang Dilakukan oleh Anak di Kota Balikpapan. Journal de Facto, 6(1), 1-20.

Pancasilawati, A. (2018). Penerapan Sanksi dalam Meminimalisir Kejahatan Anak Ditinjau dari Undang Undang Nomor 11 Tahun 2012 Tentang Sistem Peradilan Pidana Anak. Jurnal Penelitian Fenomena, 10(2), 171194.

Ronny, T., \& Nitibaskara, R. (2001). Ketika Kejahatan Berdaulat: Sebuah Pendekatan Kriminologi, Hukum dan Sosiologi, Peradaban,. Peradaban.

Sahetapy, E. L. (2016). Peranan Social Report Pada Sistem Peradilan Pidana Anak. Jurnal Penelitian Hukum, 49(3), 324-332.

Soedjono.D. (1976). Segi Hukum Tentang Narkotika di Indonesia. Jakarta: PT. Karya Nusantara.

Sosiawan, U. M. (2016). Perspektif Restorative Justice Sebagai Wujud Perlindungan Anak yang Berhadapan dengan Hukum. Jurnal Penelitian Hukum De Jure, 16(4), 425-438.

Sugiyono. (2013). Metode Penelitian Pendidikan Pendekatan Kuantitatif dan Kualitatif. Jakarta: Alfabeta.

Wiharsa, I. M. (2017). Diversi Tindak Pidana Narkotika dalam Sistem Peradilan Pidana Anak. Jurnal Magister Hukum Udayana, 6(1), 37-51. 